\title{
Housing Equity Withdrawal: Perceptions of Obstacles among Older Australian Home Owners and associated Service Providers
}

\author{
THERESE JEFFERSON*, SIOBHAN AUSTEN**, RACHEL ONG***, \\ MARIETTA E. A. HAFFNER ${ }^{* * *}$ AND GAVIN A. WOOD***** \\ * Graduate School of Business, Curtin University, GPO Box U1987, Perth, Western Australia \\ 6845, Australia \\ email: therese.jefferson@gsb.curtin.edu.au \\ ** School of Economics and Finance, Curtin University, GPO Box U1987, Perth, Western \\ Australia 6845, Australia \\ email: siobhan.austen@cbs.curtin.edu.au \\ *** Bankwest Curtin Economics Centre, Curtin University, GPO Box U1987, Perth, Western \\ Australia 6845, Australia \\ email: rachel.ong@cbs.curtin.edu.au \\ **** OTB - Research for the Built Environment, Faculty of Architecture and the Built \\ Environment, TU Delft, Building 8, P.O. Box 5043, 2600 GA Delft, The Netherlands; \\ School of Global, Urban and Social Sciences, RMIT University, GPO Box 2476V, \\ Melbourne, Victoria 3001, Australia \\ emailm.e.a.haffner@tudelft.nl \\ ***** School of Global, Urban and Social Studies, RMIT University, GPO Box 2476V, \\ Melbourne, Victoria 3001, Australia; OTB - Research for the Built Environment, Faculty of \\ Architecture and the Built Environment, TU Delft, Building 8, P.O. Box 5043, 2600 GA Delft, \\ The Netherlands \\ email: gavin.wood@rmit.edu.au
}

\begin{abstract}
Housing wealth dominates the asset portfolios of the older population in Australia and many other countries. Given the anticipated spike in fiscal costs associated with population ageing, there is growing policy interest in housing equity withdrawal (HEW) to finance living needs in retirement. This paper sheds light on homeowners' perceptions of the obstacles associated with two forms of HEW: mortgage equity withdrawal (where the in situ home owner increases his/her housing-related debt) and downsizing (where housing equity is released by moving to a lower-valued property). We uncover a series of age-specific barriers impeding older Australians' use of these forms of HEW through qualitative analysis of semi-structured interviews conducted with home owners and professional service providers in related areas of policy and practice. To that end, we recommend the development of a range of safeguards that will minimise the risk exposure and other obstacles associated with HEW for older home owners.
\end{abstract}

\section{Introduction}

The quest for home ownership can be motivated by a range of perceived benefits associated with financial and accommodation security. Increasingly, however, 
growing age-related costs and policies of fiscal austerity have also stimulated policy interest in the use of accumulated housing wealth to support retirement needs, especially aged care (Productivity Commission, 2015; Dilnot et al., 2011). Such policy interest is not surprising. In many countries, wealth accumulated in the primary home dominates the elderly's asset portfolios (Chiuri and Jappelli, 2010) helped by sustained house price increases through the mid-1990s and early 200os. These price increases and the prior deregulation of mortgage markets has prompted the introduction of innovative equity release products that allow home owners to convert housing equity into cash (Ong et al., 2013a, 2013c). This has resulted in a policy milieu in a number of countries where home owners are increasingly expected to draw on personal assets, including the primary home, to meet their welfare needs in old age (Doling and Ronald, 2010).

It is therefore important from a policy perspective to identify any obstacles that impede older home owners' ability to safely release housing wealth. If older home owners believe that the hurdles impeding housing equity withdrawal (hereafter HEW) are insurmountable, policies encouraging home owners to tap into their housing wealth will be ineffective. The nature and extent of barriers to HEW is now a central part of research agendas on asset-based welfare.

This paper presents an analysis of the perceptions of HEW amongst Australian home owners aged 45 and over. Despite a relatively large pool of European studies (see section 3), there is a lack of Australian evidence on older person's attitudes to HEW. Yet the Australian case is one well worth exploring in further detail because its welfare state has developed along distinctive lines that mark it out from many North-Western European social insurance models. The latter are organised along universal lines (e.g. Scandinavian countries) or based on the contributory principle (e.g. Germany, France, Belgium), with financial payments made in return for insurance protection against risks that pose threats to health and financial wellbeing across the life cycle (Esping-Andersen, 1990). In Australia these protections are generally means-tested and targeted at those most in need. Australian protections are often embedded, through regulation and government financial support, in the private sector, which is not normally viewed as being part of the social security system (Herscovitch and Stanton, 2008). It therefore differs markedly from the Western European context that has provided the institutional context of existing studies on attitudes to HEW.

Home ownership and the savings stored in housing assets has always been an important pillar supporting this Australian welfare state model. From the early days of Federation, mainstream political parties supported home ownership as a solution to housing problems (Dalton, 1999), and as a source of financial security in old age because mortgages are invariably paid off by retirement, when incomes typically fall. Successive Australian governments have therefore been willing to extend generous homeowner tax expenditures (such as stamp duty concessions, land tax and capital gains tax exemptions), concessionary asset tests governing 
eligibility to state pensions in retirement, and financial assistance to first-home buyers. However, in recent years, policy attention has shifted, as a range of government agencies and political commentators have identified housing equity as a potential source of retirement income that could reduce government pension and aged care spending (Productivity Commission, 2015; Actuaries Institute, 2016).

This shift has been assisted by innovative financial products that allow owners to tap into their housing equity. These mortgage equity withdrawal (MEW) products effectively turn housing wealth into an 'ATM', with borrowers free to draw down or add to their housing equity in situ (Klyuev and Mills, 2010). Forms of MEW that are not age-specific have been available for decades. A particularly popular product in Australia and the UK is the flexible mortgage. This permits in situ MEW by allowing the home owner to borrow by increasing the outstanding mortgage debt secured against their housing equity. The mortgagor can withdraw or inject funds multiple times over the term of the mortgage.

Age-specific products targeted at the elderly commonly take the form of reverse or lifetime (UK-term) mortgages. These products allow home owners in their 60 s or older to take out loans using the family home as collateral. The lender provides funds in the form of an income stream or lump sums during the loan term, but no repayments are made until the borrower dies, or the house is sold. The sale proceeds are used to repay the loan. The outstanding balance at the end of the loan comprises the original loan amount plus the interest accrued over the life of the loan. The Productivity Commission (2015) points out that the age-specific MEW market is very small, attracting only 1-2 per cent of older home owners. It is dominated by reverse mortgage loans that amount to just 0.4 per cent (AUD\$3.7b) of the AUD\$926 billion of housing equity accumulated by older Australians.

The main alternative channel for equity withdrawal has been downsizing ${ }^{1}$ from a higher value to a lower value owner-occupied home. However, only 7 per cent of HEW transactions by Australians aged 45 and over are downsizing moves (Ong et al., 2013b), leaving MEW as the most popular style of HEW among mid-to-late life Australian home owners, accounting for over eight in every ten HEW transactions over the period 2001-2010 (Ong et al., 2015).

Despite the growing policy interest in HEW, there is a dearth of Australian evidence on older persons' attitudes to HEW, despite the distinctive nature of the Australian welfare state in which retirees' achievement of outright ownership in a market-based housing system is a critical support. This paper therefore addresses an important gap in the evidence base. The findings presented in this paper also have a wider relevance for those countries moving toward market-based housing systems and more limited social insurance models, following austerity policies introduced after the Global Financial Crisis (GFC).

Section 2 provides an overview of theoretical concepts relevant to the risks associated with increasing reliance on the home as a 'pension plan' to be rolled 
out following retirement. Section 3 reviews findings from international and Australian studies of housing equity withdrawal and retirement policy issues. Section 4 shifts attention to in-depth interviews undertaken with older Australian home owners, and relevant policy actors, in 2012-13. We describe the sample and the interview schedules used to explore their experiences with and/or assessments of alternative HEW mechanisms. The findings are presented in Section 5, where we also outline a typology of obstacles to HEW, as understood by Australian home owners and policy actors. Section 6 discusses the possible policy implications of our findings.

\section{Theoretical framework}

The life-cycle economic model of consumption and saving predicts that individuals will smooth their consumption expenditure across the life cycle by saving during periods of relatively high income, and dissaving during periods when little or no income is earned (Modigliani and Brumberg, 1954). An important implication is that people will plan to drawdown accumulated savings, including those stored in housing assets, to meet their spending needs in retirement.

But this model assumes a known finite lifetime over which the individual can anticipate spending needs. An alternative theoretical approach can offer a richer analysis of HEW by focusing attention on 'longevity risk'; that is, the uncertainty about lifespans. The approach highlights how, in the absence of collective schemes to insure against longevity risk, individuals will need to save and/or accumulate assets during their working lives to meet unanticipated spending needs over an uncertain period of retirement. Importantly, the approach emphasises a potential 'insurance' or precautionary saving function for housing and other assets, which may preclude asset divestment in old age (see Austen and Ong, 2015 for an overview).

This theoretical approach also highlights how asset-based retirement income systems expose individuals to a range of risks associated with earnings variability, changes in health and care costs, interest rate volatility and other 'known unknowns'. Importantly, the difficult task of providing for one's retirement is not limited to pre-retirement life-stages. Retirees in private retirement-income systems need to make decisions about when and at what rate they should draw down their assets. Unexpected longevity, health and care needs, as well as interest rate and price changes can cause hardship in later life. Couples face additional difficulties and risks as they need to take account of different lifespans, and patterns of health and care needs.

The insurance/risk perspective on retirement incomes raises important questions about the availability and cost of market-based insurance products that hedge age-related risks and unexpected interest rate or price changes. An absence of such products and/or high insurance costs due to market failure will 
expose individuals to key risks when they are most vulnerable, with adverse consequences for individual well-being. It may also encourage households to 'self insure', for example, by holding onto assets to ensure that some resources are available to meet late-life health and care needs.

\section{Literature review}

Using the Household Income and Labour Dynamics in Australia panel survey, Wood and Nygaard (2010) report that a little over one in four respondents aged 45 years and over, but not yet retired, expect to sell their house, or move to lower cost accommodation, to help them manage financially at retirement. In 2007 and 2011, when this same question was asked, 27 per cent and 35 per cent respectively, responded in the affirmative. Thus a substantial minority of home owners appear willing to downsize their housing assets in retirement. But it is puzzling that census and survey based empirical studies find that few Australians actually downsize in retirement, and selling up is rare (Judd et al., 2014; Ong et al., 2013b). They also confirm an aversion to equity release products, so seniors are not turning to MEW in preference to downsizing (Productivity Commission, 2015). North American studies also find that elderly home owners are reluctant to downsize (Skinner, 1996) ${ }^{2}$, or use reverse mortgages to cash in housing equity (Venti and Wise, 1991).

A commonly advanced explanation for the uncommon use of in situ MEW is risk aversion that increases with age. There are now a number of qualitative and survey-based studies from various countries that confirm elderly owners' anxiety about increasing debt secured against the home (Costa-Font et al., 2010; Fox O'Mahony and Overton, 2015; Fornero et al., 2011). These anxieties are prompted by plans to preserve housing wealth as a buffer to meet emergencies (Jones et al., 2012; Naumanen et al., 2012; Haffner, 2008). Elsinga et al. (2010) summarize the findings of a European study (Demographic Change and Housing Wealth (DEMHOW)), and conclude that housing equity is a precautionary 'nest egg' (Elsinga, 2011) that owners are generally loath to drawdown. This is consistent with the self-insurance theoretical framework.

But there are competing explanations for the reluctance of the elderly to use financial instruments in order to cash in housing equity. The bequest motive is commonly cited as an important impediment (Elsinga et al., 2010; Ong et al., 2013b). Equity-release products eat into the children's inheritance. However, econometric modelling based on large sample sizes suggest that parents' bequest plans appear not to influence their intentions to HEW (Wood and Nygaard, 2010), or the actual HEW behaviour of older owners (Ong et al., 2013b). Fornero et al. (2011) and Haffner (2008) also report evidence indicating that bequest motives are an insignificant influence on housing wealth management strategies.

Fears about risk and the capacity to bequest can be allayed by downsizing. After all equity released on downsizing can be reinvested in risk-free government 
securities that yield an income. Their nominal capital value is certain and, as a liquid asset, they can be readily realised to meet urgent spending needs. However, as we noted earlier, few retirees actually downsize. The literature appeals to other reasons for this reticence; high transaction costs, including government transaction taxes (e.g. stamp duty) erode realisations (Ong et al., 2013 b). Government means tests governing eligibility for age-care services and income support programmes commonly exclude the family home, and thereby offer a financial motive to 'age in place' (Productivity Commission, 2015). Finally, planning rules that deter development of smaller, higher density housing reduce affordable downsizing options for older people, a factor that is evidenced in some qualitative research studies (Judd et al., 2014).

There is also a rich vein of sociological research that suggests seniors attach special meaning and emotional attachment to the home (Fox O'Mahony and Overton, 2015; Elsinga et al., 2010). These attachments underpin a reluctance to secure debt against homes, or move in order to release housing equity, and go beyond the risk aversion, precautionary models of economists. Elsinga et al. (2010) use the term 'loss aversion' to describe the way interviewees feared loss of their home, as well as a quality of life associated with the independence, power, respect and value associated with being an owner. Jones et al. (2012) suggest that a home's emotional value increases with age because the elderly spend more time 'at home'. Fox O'Mahony and Overton's (2015) UK study of equity release consumers also find that this emotional value is associated with feelings of belonging, control, success and freedom. While these feelings did not cause the study participants to eschew equity release, they may in fact act as barriers to equity release for others considering this option. Equity-release products' reputation for complexity is an additional barrier that can add to feelings of insecurity surrounding their use (Elsinga, 2011; Terry and Gibson, 2006).

One final but important observation sheds some doubt on the future relevance of these explanations. The puzzle we used to launch this literature review might simply reflect a cohort effect (Fox O'Mahony and Overton, 2015; Elsinga, 2011). In an important Australian study Olsberg and Winters (2005) surveyed just under 7,000 older Australians. One-third of the sample were between 50 and 60 years of age, comprising the first cohort of the Baby Boomer generation, and the remaining two-thirds were 60 years and over. The research found that baby boomers are prepared to 'spend the home' in a way that the inter-war generation are unwilling to sanction. They argue that this heralds a significant shift in the values and priorities of older Australians, with the desire to bequeath assets diminishing and being overtaken by the appeal of independence, flexibility, consumer and lifestyle choices. These values could replace the self-insurance motives governing the accumulation and use of housing wealth by future retiree cohorts. The findings pose a potentially serious threat to an idiosyncratic Australian welfare state in which retirees' achievement of 
outright ownership in a market-based housing system is one of a number of critical supports. Our study's more specific findings shed further light on this important issue. As indicated in Section 1, the evidence presented in this paper also has a wider relevance for those countries moving toward market-based housing systems, and more limited social insurance models following post-GFC austerity policies.

\section{Data and methodological approach}

Our interview data was collected as part of a mixed methods research project investigating the use of HEW by older Australian home owners. A programme of qualitative data collection and analysis explored older Australians' perceptions of HEW and complemented an analysis of survey data (Ong et al., 2013b). Two groups were the subject of semi-structured interviews. The first group are Australian home owners aged over 45 years in 2012 and 2013, who were asked about their views of and experiences (if any) with MEW and downsizing. Professional service providers, in various areas of policy and practice related to HEW, formed our second group. This phase of data collection was designed to gain insights from people active from a 'third party' perspective in a broad range of HEW contexts and experiences.

As highlighted in previous sections, our paper adds to the existing literature by shedding light on whether attitudes to HEW are indeed changing among older home owners living in a welfare state different from the Western European and British norms. In addition, it makes three further contributions through its methodological approach. First, it distinguishes between the key styles of HEW - MEW and downsizing - and the different reasons advanced by home owners reluctant to use either method of equity release. Second, it sheds light on the experiences and views of home owners who do not use HEW in order to identify the possibly distinctive barriers faced by those older home owners that chose not to engage in equity release. Third, it elicits the 'third party' views of service providers working in areas of policy and practice related to HEW. It is possible that negative experiences and views about HEW are of a sensitive, personal nature that interviewees are unwilling to discuss. Interviews with service providers gave us an opportunity to capture insights into specific issues that individual owners were reluctant to reveal. It also helps mitigate self-selection biases that may arise when home owners with negative experiences choose not to participate in the interviews.

\section{Participant recruitment and interview data collection}

Home owner participants were recruited through several different methods. An invitation to participate was included in the electronic newsletter of National Seniors, a not-for-profit organisation representing the interests of older Australians. Thirty-five people responded to this invitation. In addition, two 
TABLE 1. Summary of 27 homeowner interview participants

\begin{tabular}{llllll}
\hline Characteristic & Sydney & Adelaide & Perth & Melbourne & All locations \\
\hline Age group & & & & & \\
$45-54$ & 2 & 2 & & & 4 \\
$55-64$ & 2 & 2 & & 2 & 11 \\
$65-74$ & 2 & 4 & 3 & & 8 \\
$75+$ & 2 & & 6 & & 23 \\
Marital status & 6 & 8 & 7 & 2 & 4 \\
Partnered & 2 & & 2 & & 22 \\
Single & 7 & 6 & 9 & & 5 \\
Housing tenure & & 2 & & 2 & \\
Outright owner* & 1 & &
\end{tabular}

Note: * One participant in this group was an outright owner of a home in his wife's name. This home is leased to tenants, and the couple rent accommodation as required by their frequent relocations linked with employment commitments.

separate batches of 50 hard-copy interviews were distributed by the Council of the Ageing Western Australia (COTAWA) and the Council of the Ageing New South Wales (COTANSW); 23 people responded. Study participants completed a pro forma providing information about their personal characteristics, including: age, address, marital status and housing tenure. Twenty-five interviewees were selected to achieve diversity across these characteristics. A further two participants were recruited via snowballing to correct an initial under-representation of Sydney participants in the 45-54 years and the 55-64 years age groups.

Table 1 documents a final sample that achieves a representation across all the personal characteristics used to screen participants. The 27-participant sample is consistent with the sample sizes generally found within qualitative research studies, particularly where funding arrangements and scope of inquiry are agreed prior to commencement of the study (Mason, 2010; Morse, 2015). Haffner (2008), for example, interviewed 23 elderly people aged 70 and over to investigate links between housing and ageing issues. In later papers Colic-Peisker et al. (2015), Jones et al. (2012) and Naumanen et al. (2012) report findings from interviews with 30 home owners on the role of housing in old age; however, the 30 interviewee sample spanned the young (25-35 years), middle-aged ( $45-55$ years) and old (65 years and over). In addition, service provider interviews offer insights that reflect a large number of clients' experiences of HEW, and are therefore a conduit through which we in effect boost the sample size beyond the number of older homeowner participants.

Primary home assets have public-good characteristics: even if one individual has legal ownership of the asset, the shelter it provides is available to all household members. However, adults in a household may have different views about HEW, and discharge different decision-making roles. We therefore chose to conduct 
TABLE 2. Summary of 11 service-provider interview participants

\begin{tabular}{ll}
\hline Service provider type & $\mathrm{N}$ \\
\hline Community-based not-for-profit organisation & 3 \\
Government department & 3 \\
Private financial service provider & 2 \\
Private advisory service provider & 2 \\
Peak industry body & 1 \\
\hline
\end{tabular}

separate interviews with each partner in seven couple households. In five couple households only one person was interviewed. A further two interviews were conducted jointly with both partners at their request. Four interviews were undertaken with singles. Interview locations convenient to participants were chosen, including their homes, a researcher's university office and a participant's workplace.

The homeowner interviews covered three areas of enquiry. Firstly, they asked about housing histories and attitudes toward home ownership. Secondly, questions about perceptions, experiences and intentions regarding the uses of housing equity were posed. Thirdly, we asked interviewees about access to information and advice on HEW. The questions were piloted and then refined following the first three interviews.

In the second phase of data collection 16 invitations were sent to organisations dealing with housing and social policy issues. Nine organisations offered to take part in an interview. Table 2 lists the service provider types who were represented by 11 participants.

The interview schedule elicited service providers' views about older Australians' use of HEW, and impediments hindering the use of HEW. It also elicited opinions regarding the availability of appropriate information, advice and policy to support informed decision-making. All interviews were transcribed with the consent of participants and standard measures were employed in order to preserve confidentiality. All participants could view their transcript and make edits to ensure that their views were accurately recorded. Thematic analysis with open coding was used to identify key data categories. $\mathrm{N}^{*}$ Vivo software facilitated data management. Table 3 categorises participants according to their use of HEW.

\section{Results}

Homeowner interviewees described a number of barriers to HEW, several of which were age-related. These barriers left interview participants wary of HEW on an 'in principle' basis. Several obstacles were specific to either MEW or downsizing. 
TABLE 3. Summary of homeowner participants' HEW experience

\begin{tabular}{lcl}
\hline HEW experience & N & Interview code names \\
\hline Has used MEW & 7 & $\begin{array}{l}\text { Brian, Fiona, Frank, James, Jenny, Ken, Kerry } \\
\text { Cas downsized }\end{array}$ \\
No HEW experience & 9 & $\begin{array}{c}\text { Martin, Tara } \\
\text { Alan, Harry, Hilda, Ian, Ingrid, Les, Nick, } \\
\text { Olivia, Oscar, Peter, Sam }\end{array}$ \\
\hline
\end{tabular}

Note: One couple appears (their description lacked clarity) to have entered into a home reversion loan, which is the sale of a proportion of a home owner's equity, while allowing them to remain in the home until the owner eventually sells up (Ong et al. 2013a).

\section{Age-related obstacles relevant to HEW}

Longevity risk - underestimating life expectancy and being left with insufficient income in old age - was well understood by many of the study participants. Home owner interviewees were generally aware of the challenges posed when making longer-term financial decisions in the face of fundamental uncertainty:

... if you borrow on your house [at] too early an age, no one knows how long they're going to live and we don't know, there's so many unknown quantities... (Carol, regional centre outside of Perth, 75+)

However, our study found that age-related risks associated with HEW extended beyond longevity risk, as it is understood in economic modelling and in the design of retirement income vehicles. Indeed, representatives from community-based organisations highlighted the financial and non-financial risks that breakdown of intra-family relationships pose for housing and care. People find it emotionally painful to speak about these matters, so this is a risk not revealed by the individual participants. However, service providers are in roles where they can be privy to such cases.

A typical intra-family arrangement usually involves elderly parents selling their home to release equity and assist their child's home purchase, with the expectation of receiving informal care when required. In many cases this arrangement works to the satisfaction of all parties, but not always.

And there's a promise that there's a granny flat and then one morning, mamma wakes up and there's a 'For Sale' sign and there's no protection. (Service provider 2, community not-for-profit)

A deeper analysis suggests that particular types of risk precipitate conflicts. Firstly, the son or daughter may have under-estimated the burden of providing care to elderly parents, and little equity may remain to finance professional care:

... the daughter, the son, the carer, whoever, takes a bigger bite than what they can chew and they find that caring as time goes on is quite a stressful and onerous job and they're not prepared and they're looking for ways out ... (the parents) don't have sufficient funds to reset themselves up 
somewhere else with the care that they were promised. (Service Provider 3 , community not-forprofit)

Secondly, changing family dynamics in the offspring's household can disrupt previously agreed care and accommodation arrangements:

there's always another party to the other party and the breakdown often comes because of the other party to the other party. (Service provider 3, community not-for-profit)

Thirdly, some service providers knew of parents that MEW in order to assist their children, but parents expected their children to part or fully repay the transfer at a later date. ${ }^{3}$ However, they are exposed to default risk if their child experiences unemployment, business failure or some other catastrophic life event. Tensions are frequently exacerbated when one sibling learns that another has received financial assistance from a parent:

... the ones that we might see, is where the loan, there's some difficulty with the person, unexpected, loss of job income, business goes down and then they can't make the payment. So that's when all these things would come to light. (Service provider 2, community not-for-profit)

One participant also raised the issue of financial abuse by children as a general risk:

... I just hear stories and circumstance [s] where children have sold up properties on behalf of the parents and moved them out of homes and used their assets and things like that. And that financial abuse is very difficult... (Olivia, Sydney, 45-54)

Overall our findings confirm the importance of longevity risk as a factor deterring the divestment of housing assets in older age. The interviews therefore support the proposition that an insurance or precautionary savings approach offers richer insights than the traditional life-cycle economic model into how the elderly manage housing wealth. But they also alert us to age-related risks extending beyond traditional notions of longevity risk. Older home owners that transfer some of their housing wealth to children can be vulnerable to intra-family tensions when the implicit, or explicit, obligations of children are not reciprocated. In a homeowner society such as Australia's where owneroccupied housing has played such an important welfare role, we can expect intra-generational wealth transfers to become an increasingly important plank supporting home ownership rates among younger generations (see Barrett et al., 2015b for evidence). The reciprocal obligations and sibling rivalry accompanying these transfers is likely to become a more prominent feature of Australia's homeowning society.

\section{Age-related obstacles to MEW}

MEW was viewed as a problematic way of drawing down on capital to generate an additional income source. The association of MEW with debt was sufficient to deter owners. Some linked their aversion to MEW with specific 
concerns about possible increases in interest rates 'down the track'. These worries about repayment risks were reported by numerous participants regardless of previous experience of MEW:

I think that there's high interest rates and even though you don't have to pay it now... you have heard of people that have lost the houses by taking them out and they are still living out on the street. (Elaine, Perth, 75+)

Service providers expressed concern around consumer understanding of the links between compounding interest and debt, and the significance of exit fees following early termination:

... somebody may have a loan for $\$ 40,000 \ldots$ and their home might be worth say $\$ 500,000$, before long, that loan is up to $\$ 80-\$ 90,000$. And the exit fees, if they want to sell their home and change their minds about living in the house forever, might be $\$ 40-\$ 50$,ooo. (Service provider 2, community not-for-profit)

Accurate information and advice was also a major worry for service providers. They believed that unbiased and truthful information was not always easy to find:

... there is very little that gives an unbiased view of the advantages and disadvantages, and, at the end of the day, that's the sort of information people need in order to make decisions. (Service provider 9 , private finance provider)

Some service providers were concerned about the increasing complexity of information:

Yes, for a long time I was a believer in —excuse my Latin—caveat emptor 'Buyer Beware'. However, these days we live in such a complicated world it's hard to become fully informed. (Service provider 6, community not-for-profit)

The analysis also revealed different service provider and owner views about the hazards of MEW. While some service providers worried about owner comprehension of product information, most home owner participants felt that they could access the necessary information about equity-release products. However, their appreciation of the important financial issues was not matched by a propensity to seek specialist advice. Instead, some participants preferred to obtain advice from trusted family and friends:

... if you want to ask a specific question, well you go and ask the friends and they will say 'Oh yeah, so and so has done that or found information about that'. (Ian, Adelaide, 65-74)

These tactics might reflect a belief that intelligence collected from trusted friends and relatives is more reliable than that provided by financial institutions. Several home owners doubted the motivations of those selling MEW products:

I just don't think they are a good idea. I think there are a lot of sharks out there-a lot of risks. (Elaine, Perth, 75+) 
Both home owners and service providers recognised the threat to bequest plans that MEW posed, as illustrated in the following quotes:

We worked hard for what we've got and if there's anything left my kids can have it, not the bank. (Elaine, Perth, $75+$ )

... It just means the equity in their property is running out rapidly; depending on how long they live, there will be far less there for their estate, for their beneficiaries, for their children, their grandchildren, what have you. (Service provider 1, private finance provider)

Overall, the viewpoints uncovered indicate the need for a deeper understanding by policy practitioners of older home owners' anxieties about MEW. For instance, improvements in the availability of unbiased and accessible information on MEW products through channels that older home owners trust. Importantly, the analysis also suggests that concerns about the implications of MEW for bequest plans remain important, a finding at odds with Olsberg and Winters (2005). A mortgage-free house seems to have a special status which is to be preserved for inheritance by children. It is conceivable that parents find the idea of debt being inherited by their children unsettling, even if it is secured against a home that is expected to increase in value. But the interview material also leads us toward other explanations of an antipathy to MEW. In a world where financial markets fail to provide products that allow owners to hedge unexpected interest rate or house price changes there is an understandable reluctance to borrow in later years of the life course, when incomes typically decline. But the strong aversion to MEW might also have deeper foundations; Australia's welfare provisions for the elderly have long rested on the assumption that the vast majority will enter old age having paid off their mortgages. A means tested age pension that is low by international standards could nevertheless support a reasonable standard of living because wealth stored in owner occupied housing has always been exempt from these means tests. This is well understood and from it has emerged an antipathy to debt secured against the home in old age.

\section{Age-related obstacles to downsizing}

A key contribution offered by this study is the distinction made between different styles of HEW. The attitudes toward and experiences with downsizing differed significantly from those associated with MEW products. Interviewees raised concerns about a mixture of risks and financial costs that hamper intentions to downsize. Downsizing was more closely linked with adverse life events:

... goodness, if your husband dies, your life-long mate, you know, is this, you've got to now not only sell the house, you've got to downsize and then move to a whole new environment, I think, how did you manage that? (Glenda, Perth, $75+$ )

A service provider noted that when downsizing was precipitated by adverse life events, time pressures constrained information gathering and considered planning: 
And that's the problem we get mainly, coming [to us] under crisis, and then they have to make a quick decision because it's not [in] the planning. (Service provider 8 , private advisory service)

A context of crisis and adversity is a challenging environment within which to make important and complex decisions that are emotionally charged. The hazards due to inaccessible and inadequate information are then magnified.

Participants understood that downsizing involved a related decision about how to 'store' the equity released. The 'store of value' question often prompted home owners to express concerns about the price volatility of other assets, particularly shares. Homeowner interviewees argued that housing values are relatively stable, and this makes housing a more desirable investment. The global financial crisis of 2008 and subsequent slump in stock markets seems to have exercised a strong influence on homeowner attitudes:

... you could have thousands of dollars tied up in shares but at the whim of some stock broker or say what happens on Wall Street, you could suddenly lose most of it. Whereas with a property, the values in housing fluctuate, but usually I think you end up pretty well breaking even. (James, Adelaide, 55-64)

The legacy of an Australian welfare state in which home ownership is such an important pillar is again relevant. The age pension means tests that exempt the family home discourage downsizing because the equity released put age pension entitlements at risk. Furthermore, eligibility for the age pension acts as a 'passport' to other benefits such as reduced energy bills, and concessions on public transport fares and motor vehicle registrations. These concerns are an important consideration in financial cost and benefit evaluations of downsizing:

I suppose if we downsize we would have money and ... it'll affect ... the age pension. (Jenny, Adelaide, 55-64)

Moreover financial anxieties are aggravated by transaction costs on downsizing that eat into the housing equity released:

They shouldn't charge so much, transferring and stamp duty when you're trying to downsize ... Like you pay to get out of this place but then you pay to get into another place ... (Jenny, Adelaide, $55-64)$

Several homeowner participants also feared downsizing due to the loss of familiar and friendly neighbours. Some would also regret the likely sacrifice of living space, making it more difficult to accommodate visiting (grand-) children. Alan's situation is illustrative:

We've got two daughters living in the eastern states and they visit when they can, and grandchildren, so it's nice to have a nice house to come to. And that was sort of one of the arguments against downsizing. (Alan, Perth, 75+)

These concerns were echoed by a service provider, who noted that: 
... there is very clear evidence ... [that] there is a strong desire to stay in place. (Service provider 9 , private finance provider)

Relocation into retirement villages is sometimes considered as a downsizing option. Glenda and Graham downsized to a 'lifestyle village', but unexpectedly encountered high and increasing costs to cover the maintenance of communal facilities which caused considerable anxiety:

... we've been here six months, well not even. The quarterly rate, the fortnightly rates, have gone up three times. (Glenda, Perth, $75+$ )

Service providers remarked on the appeal of retirement villages as a downsizing option, but warned that it can result in modest equity release and reiterated concerns about ongoing fees; this is clearly an important risk that should be considered when contemplating a move into retirement villages:

... they're not cheap and you've got to be moneyed to both buy into them, which means selling your property, and to stay there as well. (Service provider 6, community not-for-profit)

The analysis highlights an important distinction between the perceived obstacles of MEW and downsizing. It is clear that downsizing is hampered by not just financial obstacles that also deter MEW, but non-financial considerations that require a housing supply solution. Often, older home owners (and their adult children) have strong emotional attachments to their family home and local community, but shortages of appropriate dwellings in neighbourhoods where older owners would like to stay prevent them from downsizing (Ong et al., 2013b; Judd et al., 2014).

\section{Summary and discussion of policy implications}

Our qualitative evidence documents numerous hazards and barriers that cause Australian home owners to eschew HEW. Our interview material generally confirms the conclusions from similar studies in other developed countries. But we also unearth new findings that offer a more nuanced understanding of the obstacles that deter older home owners from engaging with HEW. It seems that age-related risks extend beyond traditional notions of longevity risk to encompass the hazards associated with breakdown of intra-family and intergenerational reciprocal arrangements. These risks include offspring underestimating the burden of care, changing dynamics within a son or daughter's household, the elderly parent's exposure to default risk when the child is unable to make promised repayments of transfers, inter-sibling tensions around elderly parent's HEW decisions, and the potential for financial abuse of the elderly person. Furthermore, our research suggests that elderly home owners remain strongly averse to the use of debt to unlock housing wealth, and are suspicious of MEW products. These attitudes and values could well reflect the historic importance of 
home ownership as a pillar supporting welfare in old age, a role that has become institutionalised through favourable fiscal settings that most Australians strongly support. However, it may also be linked to a reluctance to pass on debt secured against the family home to the next generation.

If governments want to encourage the release of housing equity in later life while moving increasingly towards austerity-driven systems with limited social insurance models, they will at the very least need to develop policy safeguards that reduce owners' risk exposure, and eliminate other obstacles to HEW. The rest of this concluding section offers some policy recommendations.

MEW products are complex and service providers believe that the information and advisory services available to older home owners is deficient. A policy priority should be the design of comprehensive, objective materials - and a dissemination strategy - that addresses this important information gap. The materials provided to older home owners should also canvass intrafamily relationship issues. However, it has to be recognised that older home owners typically mistrust financial specialists working in the field. Hence, some consideration would need to be given to the kinds of channels through which such information can be effectively disseminated to older home owners. Efforts in this direction have been made through the establishment of Australia's National Information Centre on Retirement Investments (NICRI). However, few of the home owner participants in our study appeared to know of NICRI's existence, or other advice and support services.

It is likely that coming years will witness the introduction of innovative equity release products that lower home owners' exposure to important risks and address bequest concerns that are specifically associated with debt-financed products. Smith (2009) has proposed making a distinction between the investment and consumption values of the home, to create a form of equity finance which in essence allows the home owner to spend housing wealth, without increasing mortgage debt. Equity-oriented products are already starting to emerge in Australian markets through various providers (DomaCom, 2013; Popi Australia, 2011). Others have proposed that the investment component of the family home be turned into an independent tradable product in financial markets via the use of housing derivatives whose value reflects underlying house-price movements (Smith, 2010). This would in principle alleviate the home owner's investment risks through asset diversification, and split the investment risk from the consumption of housing services.

Policy can play a role in researching these innovations and assisting the development of new financial products that insure owners against downside risks, as Terry and Gibson (2006) also argue for the UK. However, Price and Livsey (2013) point out that investment motives, complexity and uncertainty characterise modern housing markets. There will be a widening gap between those who can draw on their own high levels of human capital as well as employ 
financial advisors, and those left behind because they are unable to acquire the expertise necessary to function in today's market environment. The study also argues that even if suitable insurance products were available to hedge risks, low-income elderly owners will be unable to afford them.

The Government will probably have to play a critical role as a riskinsurance provider. A relevant international example is the United States Federal Government's Home Equity Conversion Mortgage initiative, which dominates the equity release market (Alai et al., 2013). In Australia, the Productivity Commission has called for the introduction of HEW schemes that allow home owners to draw down their housing equity to meet aged care costs up to a specified limit. But the Productivity Commission (2011) recommends government backing for these products to promote their market penetration.

Downsizing to release housing equity in old age raises yet another set of policy issues. Our research confirms elderly owners' fears of social isolation following residential moves late in life. These worries may be allayed if people bring forward downsizing moves earlier in life. But how policy could be designed to promote 'early' moves is unclear. Increasing the range of housing options within existing neighbourhoods is commonly advocated. However, more flexible planning codes are needed if this is to be achieved in the inner and middle ring of suburbs in Australian cities.

Downsizing is also hindered by Australian tax-benefit settings that financially penalise moves to lower value properties. Ong et al. (2013b) found that stamp duty can eat into 8-10 per cent of the housing equity that older home owners release on downsizing. Furthermore, the same study found that 60 per cent of older owners' downsizing moves result in lower social security payments. These costs are especially serious obstacles for financially stressed older home owners who might benefit most from downsizing. Reform to tax-benefit settings could ease these disincentives. For example, there is a case for stamp duty and means-test exemptions on equity released by income-poor older Australians.

These recommendations typically involve either increased expenditures or reduced revenue. They will be resisted in a policy context favouring fiscal austerity. However, the reforms could have important benefits, if the resulting housing equity withdrawal proves to be a viable pension plan enabling some incomepoor elderly to meet acute spending needs in retirement.

There are, however, some important economy wide caveats. The housing wealth of older persons is vulnerable to downturns in housing market and economic conditions. The favourable economic circumstances benefiting baby boomers' housing asset accumulation years may not be repeated again during the wealth accumulation years of subsequent generations. If house prices in Australia undergo the sharp declines that occurred in Europe during the 2008 global financial crisis, housing wealth will prove to be an unreliable asset base to draw on in order to meet retirement needs when needed. In addition, the reforms 
proposed in this paper are of no assistance to income-poor lifetime renters, and their numbers could grow if recent falls in home ownership are sustained.

\section{Acknowledgements}

This work was supported by the Australian Housing and Urban Research Institute (AHURI) grant number 84001 . The findings and views reported in this article, however, are those of the authors and should not be attributed to AHURI.

\section{Notes}

1 The other HEW option is 'selling up' an owner-occupied home and renting. A multiple property owner can also exercise MEW and downsizing with respect to second homes, or investment properties.

2 Between 1984 and 1989, Skinner (op cit.) finds that only 8.4 per cent of the elderly moves to a cheaper house, and such home owners have typically experienced an income downturn, or unexpected shocks such as health events, divorce and bereavement.

3 Barrett et al. (2015a, table 1) estimate that 5.9 per cent of Australian adults receive a parental cash transfer in any given year.

\section{References}

Actuaries Institute (2016), Unlocking Housing Wealth-Options to Meet Retirement Needs, Green Paper: Actuaries Institute of Australia.

Alai, D., Chen, H., Cho, D., Hanewald, K. and Sherris, M. (2013), Developing Equity Release Markets: Risk Analysis for Reverse Mortgages and Home Reversions, Working Paper No. 2013/o1, ARC Centre for Excellence in Population Ageing Research.

Austen, S. and Ong, R. (2015), The Use of Home Equity to Fund the Consumption Needs of Retirees: a Selective Review of Literature on Issues and Potential Risks, Bankwest Curtin Economics Centre Working Paper Series 15/5, Perth: Curtin University.

Barrett, G., Cigdem, M., Whelan, S. and Wood, G. (2015a), The Relationship between Intergenerational Transfers, Housing and Economic Outcomes, Positioning Paper No.163, Melbourne: Australian Housing and Urban Research Institute.

Barrett, G., Cigdem, M., Whelan, S. and Wood, G. (2015b), The Relationship between Intergenerational Transfers, Housing and Economic Outcomes, Final Report No.250, Melbourne: Australian Housing and Urban Research Institute Limited.

Chiuri, M. C. and Jappelli, T. (2010), 'Do the elderly reduce housing equity? An international comparison', Journal of Population Economics, 23:643-663.

Colic-Peisker, V., Ong, R. and Wood, G. (2015), 'Asset poverty, precarious housing and ontological security in older age: an Australian case study', International Journal of Housing Policy, 15(2): 167-186.

Costa-Font, J., Gil, J. and Mascarilla, O. (2010), Housing market, wealth and 'self-insurance in Spain in Smith, S. J., and Searle, B. A. (Eds.) (2010), The Blackwell Companion to the Economics of Housing: The Housing Wealth of Nations, Wiley-Blackwell, Chichester.

Dilnot, A., Warner, N. and Williams, J. (2011), Fairer Care Funding: The Report of the Commission on Funding of Care and Support, London: UK Commission on Funding of Care and Support, Available: http://www.thirdsectorsolutions.net/assets/ files/Fairer-Care-Funding-Report\%2oDilnot\%20July\%202011.pdf.

Doling, J. and Ronald, R. (2010), 'Property-based welfare and European home owners: How would housing perform as a pension?' Journal of Housing and the Built Environment, 25:227-241.

DomaCom (2013), DomaCom Fast Facts: Fractionalised property investment ('FPI'), no publisher orplace of publication given.

Elsinga, M. (2011), 'A qualitative comparative approach to the role of housing equity in the life cycle', International Journal of Housing Policy, 11(4):357-374 
Elsinga, M., Jones, A., Quilgars, D., and Toussaint, J. (2010), Households' Perceptions on Old Age and Housing Equity, Combined Report WP2, NL, DEMHOW.

Fornero, E., Rossi, M. C. and Cesira Urzi Brancati, M. (2011), Explaining Why, Right or Wrong (Italian) Households do not like Reverse Mortgages, Netspar Discussion Paper No 09/2011086.

Fox O'Mahony, L. and Overton, L. (2015), 'Asset-based welfare, equity release and the meaning of the owned home', Housing Studies, 30(3): 392-412.

Haffner, M.E.A. (2008), 'Savings for old age? Housing wealth of the Dutch elderly', Housing, Theory and Society, 25(2):110-131.

Herscovitch, A. and Stanton, D. (2008), 'History of social security in Australia', Family Matters, 80:51-58.

Jones, A., Geilenkeuser, T., Helbrecht, I. and Quilgars, D. (2012), 'Demographic change and retirement planning: comparing household's views on the role of housing equity in Germany and the UK', International Journal of Housing Policy, 12(1):27-45.

Judd, B., Liu, E., Easthope, H., Davy, L. and Bridge, C. (2014), Downsizing Amongst Older Australians, Final Report No. 214, Melbourne: Australian Housing and Urban Research Institute.

Klyuev, V. and Mills, P. (2010), 'Is housing wealth an 'ATM"? The relationship between household wealth, home equity withdrawal, and savings rates', in Smith, S. J. and Searle, B. A. (eds) 2010, The Blackwell Companion to the Economics of Housing: The Housing Wealth of Nations, Chichester, West Sussex: Wiley-Blackwell, pp. 58-81.

Mason, M. (2010) 'Sample size and saturation in PhD studies using qualitative interviews', Forum: Qualitative Social Research, 11(3):Article 8.

Modigliani, F. and Brumberg, R. (1954), Utility analysis and the consumption function: an interpretation of cross-section data, in: K.K. Kurihara, (Ed), Post Keynesian Economics, New Brunswick: Rutgers University Press, pp. 388-436.

Morse, J.M. (2015), 'Analytic strategies and sample size' Qualitative Health Research, 25(10):13171318.

Naumanen, P., Perista, P. and Ruonavaara, H. (2012), 'Homes as old age security? Households' perceptions of housing and elderly care in Finland and Portugal', International Journal of Housing Policy, 12(1):47-68.

Olsberg, D. and Winters, M. (2005), Ageing in Place: Intergenerational and Intrafamilial Housing Transfers and Shifts in Later Life, Final Report No. 88, Melbourne: Australian Housing and Urban Research Institute.

Ong, R., Haffner, M., Wood, G., Jefferson, T. and Austen, S. (2013a), Assets, Debt and the Drawdown of Housing Equity by an Ageing Population, Positioning Paper No. 153, Melbourne: Australian Housing and Urban Research Institute.

Ong, R., Jefferson, T., Wood, G., Austen, S. and Haffner, M. (2013b), Housing Equity Withdrawal: Uses, Risks, and Barriers to Alternative Mechanisms in Later Life, Final Report No. 217, Melbourne, Australian Housing and Urban Research Institute.

Ong, R., Parkinson, S., Searle, B. A., Smith, S. J. and Wood, G. (2013c), 'Channels from housing wealth to consumption', Housing Studies, 28(7): 1012-1036.

Ong, R., Wood, G., Austen, S., Jefferson, T. and Haffner, M. (2015), 'Housing equity withdrawal in Australia: prevalence, patterns and motivations in mid-to-late life', Housing Studies, 30(7):1158-1181.

Popi Australia (2011), Pension Information Guide; Remember Your Dreams, Popi Australia Pty Ltd, no place of publication given.

Price, D. and Livsey, L. (2013), "Financing later life: pensions, care, housing equity and the new politics of old age', in Ramia, G., Farnsworth, G. and Irving, Z. (eds) (2013), Social Policy Review 25: Analysis and Debate in Social Policy, Bristol: The Policy Press, pp. 67-88.

Productivity Commission (2011), Caring for Older Australians, Report No. 53, Final Inquiry Report, Canberra: Productivity Commission.

Productivity Commission (2015), Housing Decisions of Older Australians, Commission Research Paper, Canberra. 
Smith, S. J. (2009), 'The D-word', Inside Housing, 24 May, pp. 1-2.

Smith, S. J. (2010), 'Care-full markets: Miracle of mirage?' The Tanner Lectures on Human Values, Clare Hall, Cambridge University, 1 November.

Skinner, J. S. (1996), 'Is housing wealth a side show? In Wise, D. (ed) Advances in the Economics of Aging, Chicago, IL: University of Chicago Press, pp. 241-268.

Terry, R. and Gibson, R. (2006), Obstacles to Equity Release, Joseph Rowntree Foundation, York.

Venti, S. F. and Wise, D. A. (1991), 'Aging and the income value of housing wealth', Journal of Public Economics, 44:371 lic E.

Wood, G. A. and Nygaard, A. (2010), Housing Equity Withdrawal and Retirement: Evidence from the Household Income and Labour Dynamics in Australia Survey in Smith, S. J. and Searle, B. A. (eds) The Blackwell Companion to The Economics of Housing: The Housing Wealth of Nations, Chichester: Wiley-Blackwell, pp. 257-278. 